\title{
Infectious complications in patients with ventricular assist device HeartMate II
}

\author{
M Konarik*, O Szarszoi, I Netuka, J Maly, J Pirk, M Urban \\ From 23rd World Congress of the World Society of Cardio-Thoracic Surgeons \\ Split, Croatia. 12-15 September 2013
}

\section{Background}

Late infections (more than month post implantation) seem to be significant factor of higher morbidity and mortality in patients with implanted mechanical circulatory support (MCS). The aim of our study was to evaluate occurrence of infectious complications (driveline, pump-pocket) in patients with implanted MCS.

\section{Methods}

Data of patients $(\mathrm{n}=106)$, whom was implanted MCS HeartMate II in indication "bridge to transplant" from 11.12.2006 to 3.4.2013 were retrospectively analyzed. Infections were diagnosed on the base of macroscopic finding, positive wound cultivation and laboratory markers of inflammation.

\section{Results}

$82(77.4 \%)$ patients were without infection, 7 (6.7 \%) patients developed pump-pocket infection and in 17 (16\%) patients occurred driveline infection. Patients were divided according to driveline technical implantation to three groups: 58 patients with classic/direct technique, 12 patients with "C-shape technique- velour coated" and 36 patients with „C-shape technique - plastic exit site“. Driveline infection was observed in 13 patients with direct technique (0.28 patient per year), in 3 „velour coated“ patients ( 0.20 patient per year) and in 1 patient with "plastic exit site"( 0.068 patient per year). From this group 15 patients were successfully transplanted, 1 device was explanted, 6 patients died (only 2 patients on infection related complications) and 1 patient is currently on waiting list.

* Correspondence: konarikmiroslav@gmail.com

Department of Cardiovascular Surgery, Institute for Clinical and Experimental Medicine, Prague, Czech Republic

(C) 2013 Konarik et al; licensee BioMed Central Ltd. This is an Open Access article distributed under the terms of the Creative Commons Attribution License (http://creativecommons.org/licenses/by/2.0), which permits unrestricted use, distribution, and reproduction in any medium, provided the original work is properly cited.

\section{Conclusion}

Late infections are the relevant factor of morbidity and mortality. Despite driveline or pump pocket infections $67 \%$ patients were successfully transplanted or explanted after receiving an appropriate treatment. C-shape method of driveline implantation, especially its plastic site variant, seems to be the method of choice.

Published: 11 September 2013

doi:10.1186/1749-8090-8-S1-P74

Cite this article as: Konarik et al.: Infectious complications in patients with ventricular assist device HeartMate II. Journal of Cardiothoracic Surgery 2013 8(Suppl 1):P74.
Submit your next manuscript to BioMed Central and take full advantage of:

- Convenient online submission

- Thorough peer review

- No space constraints or color figure charges

- Immediate publication on acceptance

- Inclusion in PubMed, CAS, Scopus and Google Scholar

- Research which is freely available for redistribution \\ C Bïomed Central}

